direitos fundamentais do legislador nacional no ato de transposição de uma diretiva.

88 Cf. o acórdão do TJ de 21 de Setembro de 1989 Hoechst/Comissão, processos apensos 46/87 $227 / 88$, Colect. p. 2859 , ponto 18 , com o acórdão do TEDH de 16 de Fevereiro de 1992, Niemitz, Série A, n $251-\mathrm{B}$, pontos 29 e 31 .

89 Segundo o artigo 50 da CEDH, "se a decisão do Tribunal declarar que uma decisão tomada ou uma providencia ordenada por uma autoridade judicia ou qualquer outra autoridade de uma Parte Contratante se encontra, integral ou parcialmente, en oposição a obrigaçoes que derivam da presente Convenção, e se o direito interno da Parte só por forma inperferta permalr rencelar as corequencias da- concederá à parte lesada, se for procedente a sua causa, uma reparacão razó́vel.

90 Ver por exemplo a decisāo da Comissão Europé dos Direitos do Homem lórgão encarregado de "filtrar" os recursos interpostos para o TEDH) de 8 de Maio de 1985, Dufay/bélgica e Comunidade Européia, Common Market Law Reports, 1987, p. 57.

$91 \mathrm{Cf}$. a decisão da Comissão Européia dos Direitos do Homem de 9 de Fevereiro de 1990, M. \& Co./República Federal da Alemanha, Décisions et Rapports, vol. 64, p. 138

92 Sobre o tema ver a sintese particularmente incisiva de Jörg Pipkorn, "La Communauté européenne e la Convention europenne des drolls de lhomme" w Trimestrielle des Droits de l'Homme, 1993,

\title{
As Principais Teorias de Direito Penal, Seus Proponentes e Seu Desenvolvimento na Alemanha
}

PETER WALTER ASHTON

Professor Titular de Direito Comercial e Mercado de Capitais nas Faculdades de Direito da UFRGS e da PUC/RS

\section{INTRODUÇÃO}

\section{Razão e Fim/Objetivo da Pena}

Porque deve ser punido o autor delinqüente? $\mathrm{O}$ que se pretende obter/conseguir com a aplicação da pena?

0 problema assim colocado pelas perguntas acima, que envolve a explicação e justificação da pena é antigo. Uma resposta que seja aceita por todos até hoje ainda não foi encontrada.

Todas as tentativas de solução da questão (vexata questio) partem de três proposições:

Segundo a teoria absoluta a pena é a retaliação e a expiação.

Retaliação da sociedade imposta pelo estado e expiação do ato delito praticado pelo delinqüente. A teoria absoluta não se preocupa em ser meio de combate à criminalidade. Vale o principio: Punitur, Quia Peccatum Est

Pune-se e deve se punir porque foi cometido um delito.

O representante mais famoso desta teoria é Immanuel Kant. E conhecido o famoso exemplo por ele posto: Se a sociedade civil resolver auto dissolver-se, com a concordância de todos os seus cidadãos, mesmo assim, caso esta sociedade habitar uma ilha e resolver abandoná-la espalhando-se pelo mundo, o último assassino condenado e preso teria que ser executado, antes do abandono final da ilha pelo último membro do povo. Isto deverá assim acontecer para que cada um receba a punição equivalente aos seus atos e a divida de sangue não permaneça vinculada ao povo. Segundo Kant (1724-1804) as leis penais obrigam todo homem não diminuir ou lesionar a liberdade externa do co-cidadão. Destarte as leis penais formam ou arvo- ram-se em imperativos categóricos, que devem ser obedecidos sem questionamento. 1

As teorias relativas preocupam-se com os fins e objetivos da pena. Para caracterizar a preocupação central destas teorias relativas é importante a formulação dada por Seneca (filósofo romano, educador de Nero - 4aC-64-dC).

Nemo prudens punit, quia peccatum est, sed ne peccetur

Ninguém que é prudente, pune porque foi cometido um delito, mas pune (sim) para que no futuro não sejam cometidos delitos.

Portanto a preocupação central destas teorias é envidar esforços para evitar o cometimento de futuros delitos, a prevenção de delitos. Dependendo sobre quem a aplicação da pena deve exercer influência e efeitos há duas formas de prevenção:

a) o fim e objetivo da aplicação da pena ao delinqüente pode ser visto no efeito que a aplicação desta pena tem sobre outros, terceiros. que poderão ser, desta forma, atemorizados para não delinqüir. É a teoria da prevenção geral2 20 representante mais famoso desta teoria foi Paul Johann Anselm von Feuerbach, que reforçou a sua teoria penal com a idéia da coação psicológica do possivel e futuro delinqüente em potencial. Sendo o delito um ato dos sentidos, deve ser combatido, negativado por fortes imagens negativas da pena. 0 potencial delinqüente que tiver tendências de delinqüir deve ser impedido psicologicamente de atuar.

b) A teoria da prevenção especial moderna (para não confundir com as teorias de prevencão especial antigas de Christoph Carl Stuebel (1764-1827) e Karl Ludwig Wilhelm von Grolmann (1775-1829), preocupa-se com o delin- 
qüente individual. A pena deve afeiçoar-se ao delinqüente. $O$ representante mais famoso desta teoria é Franz von Liszt. Segundo esta teoria o delinqüente ou deverá ser afastado do convívio com a sociedade (medidas de segurança), ou deverá ser advertido do cometimento de delitos futuros, ou deverá ser ressocializado através do processo da execução da pena para reintegrarse na sociedade. Tratando-se de um delinqüense na sociedade. Tratando-s te particularmente perigoso podem ser tomadas medidas de segurança e de melhoria do comportamento do delinqüente especiais, para evitar, na medida do possivel delitos futuros. Diversamente ao que acontece com a pena, estas medidas não implicam num julgamento social ético de sem valia.

As teorias de unificação, ou unificadoras, procuram compreender a natureza da pena a partir de uma combinação das explicações e justificativas contidas nas teorias precedentes.

O código penal alemão em vigor incorpora elementos de todas as teorias. Representa um compromisso que surge das compreensões atualmente predominantes na politica criminal alemã. Assim mã. Assim 0 artigo 46 alinea $1^{\underline{a}}$ do código alemão parte, para a aplicação da medida da pena, da teoria absoluta, da teoria da retaliação, mas o efeito da pena sobre o comportamento futuro do autor do delito (teoria da prevenção especial) também é levado em consideração. Nos artigos 47 e 56 estão presentes nitidamente elementos da teoria da prevenção geral, eis que são normas incluidas "para proteger a ordem juridica. "Já 0 artigo $2^{\circ}$ da lei das execuções penais, con sidera de igual valia e importância a preocupação com a ressocialização do delinqüente e 0 desejo de proteger a comunidade do cometimento de outros delitos subseqüentes de parte do apenado.

Na prática penal alemã o raciocinio da retribuição ou retaliação da pena ganha de importância na medida em que aumenta o peso e a importância da pena, enquanto que se abre espaço e importância à ressocialização na medida em que 0 ato a ser punido é menos gravoso quanto à pena a ser aplicada.

Exemplos podem ser dados em separado (página 101 - Dieter Fuchs e Ewald Schellenberger "Recht".

\section{O DIREITO PENAL NA ALEMANHA NO \\ SÉCULO 19. AS MUDANCCAS DA ESTRUTURA SOCIAL E DA CONCEPÇÃO DO ESTADO. FR ANZ VON LISZT E A ESCOLA SOCIOLÓGICA DO DIREITO PENAL}

O pensamento jurídico do século 19 que tinha criado 0 estado constitucional bem como os códigos penais e de processo penal com a orientação liberal e de estado de direito, era produto do homem cidadão, aquela classe média culta, da qual surgiram os grandes pensadores, poetas e músicos da época, e cujas realizaçōes nos campos da cultura, das ciências, das artes e da técnica, lhe outorgava o direito de participar da determinação do futuro politico de cada povo. Testa figura abstrata do "homem cidada ", ta bem definida, em rel bem definida, em relação a Alemanha, por W.H. Riehl e pelo famoso Gustav Freytag, vivia a ética kantiana e aquele humanismo que desde os albores do iluminismo foram as forças impulsionadoras na história do direito penal alemão. Enquanto este tipo humano, esta classe média culta, podia ser considerada como sendo a face representativa do povo alemão, justificava-se considerar o pensamento e as idéias liberais em relação ao estado de direito, bem como o pensamento juridico-politico acerca do direito penal como o pensamento correto e também era correto considerar o direito penal dele oriundo e por ele gerado como sendo o autêntico direito penal alemão.

Todavia é uma das tragédias da história do direito do povo alemão que a partir do momento cronológico em que os conceitos liberais do estado de direito, da constituição e das instituiçōes do direito em geral, poderiam ter se afir mado e começado a funcionar, o tipo humano acima descrito, o homem cidada ja não mais acima descito, o homem cidadăo, ja não mais ra social do povo alemão daquela época. $O$ tremendo desenvolvimento da técnica na Alemanha a partir da quinta década do século 19 , os desdobramentos gigantescos econômicos e industriais após a unificação, num só estado, do povo alemão (1871), o surgimento das metrópoles e as concentrações industriais, embora tivessem resultados empolgantes na área da cultura, criaram também enormes ajuntamentos de massas operárias e de miséria, que foram os núcleos de tremendas tensões sociais e políticas. Forma-se o quarto estado, o proletariado, que passa a ser um fator político com posições opostas, antagônicas, a tudo que até então era representado pela classe média. Fator politico com repercussão e importância cada vez mais com 0 perigo que estes contrastes sociais bruta significava, não foi reconhecido e até mesmo ignorado por aquela parcela de cidadãos burgueses, que era a sustentadora do progresso econômico e que representava aquela parcela da classe média alemã mais rica e com mais poder econômico.

Nesta liderança de empresários, quase todos oriundos da classe média, que deveria ter se mantido fiel aos verdadeiros princípios ético-liberais, começaram a formar-se mudanças preocupantes de natureza ético-moral. A idéia liberal como foi traçada por Kant, com a sua caracterização pelo imperativo categórico e o seu "ser comprometido humanisticamente em relação a tudo que é humano e do homem", perdeu-se.

Para esta nova classe empresarial alemã, das
timas três décadas, principalmente, do século últimas três décadas, principalmente, do seculo
passado, "liberal" significava liberdade incondicional de todos os compromissos e principios ético-morais, para poder concentrar todas as forças disponiveis na caça sem tréguas da riqueza, da honra e da glória externas. $\mathrm{O}$ idealismo moral, do qual partira a influência intelectual do liberalismo do início do século 19 , teve que ceder, com honrosas exceçōes entre as lideranças empresariais daquela época, a um crasso e vulgar materialismo, totalmente cego em relação a uma grande tarefa social: assegurar a este novo quarto estado, a este novo proletariado, condições humanas de sobrevivência, que lhe assegurassem uma participação nas conquistas econômicas e culturais dos novos tempos. Faltou também assegurar ao operariado, de parte das lideranças empresariais e da classe média, um sentimento de compreensão e preocupação com os problemas do operariado, colaborando na solucão dos mesmos, instilando ao mesmo tempo confiança, amor e respeito para com 0 estado de direito que estava surgindo.

Contrário ao que era de se esperar, forma-se

no operariado industrial alemão, no fim do sé- culo 19, a mera expectativa de uma existência proletária abjetamente pobre e massificada. $\vec{E}$ certo que o estado constitucional e de direito já então existente na Alemanha, assegurava também a estas massas as "liberdades" individuais, mas no estado de miséria em que o proletariado industrial se encontrava, tais liberdades so podiam significar distorcooes quase que inúteis. 0 da liberdade conratual, quando os contratos de trabalho eram todos ditados por empregadores economicamente poderosos? O que adiantava o conceito e a idéia abstrata da existência de uma personalidade autônoma e moral, quando a sua vida diária se resumia em coerção, pressão e não-liberdade? Quando a sua total dependência e insuficiência era assinalada no preciso momento quando, perdendo o emprego, passava a depender de si mesmo? A inimizade em relação ao homem cidadão do seu próprio povo, empurrava o operariado proletarizado para uma outra liderança, para uma liderança revolucionária, optando não pela classe do cidadão burguês, mas pela solidariedade internacional da classe do operariado. O proletariado industrial alema, do último terço do século 19 queria ser incorporado a sociedade civil e exigia do estado que prestasse muito mais serviços, do que ser meramente uma instituição de proteção de direitos. 0 proletariado alemão passou a exigir que 0 estado passasse a ser onipresente para ele que assegurasse uma existencia segura e que não-somente ( proporcionasse segurança mas ainda sentido conteúdo para a vida.

A função e a compreensão do estado não podiam restar intocados destas mudanças fundamentais na estrutura social alemã. A evolução estatal sai dos caminhos e trilhos de uma politica meramente liberal e se encaminha para o estado com orientação política social, para o estado do bem-estar social. Com esta nova tendência deslocam-se as fronteiras de atuação do estado na Alemanha e o relacionamento do estado para com o individuo é colocado sob a influência de novos pontos de vista, de novas perspectivas e de novas perguntas, alterações que também passam a afetar o pensamento juridico na área do direito penal de maneira extraordinária. 
A IMPORTÂNCIA DA ESCOLA HISTÓRICA DO DIREITO

O racionalismo exagerado da época do iluminismo, já tinha sido temperado pela escola histörica do direito. De acordo com o posicionamento que pode ser considerado certo, a escola histórica do direito mostrou que o direito positivo, o direito em vigor num determinado momento histórico, somente pode ser compreendido na sua totalidade e na sua maneira de ser, como algo formado e afeiçoado do conjunto da evolução histórica, e que portanto o conhecimento o saber histórico são os meios imprescindiveis para poder obter-se um posicionamento distanciado e critico em relação ao direito em vigor permitindo uma análise intelectual segura $\mathrm{e}$ autônoma. Estas são as conquistas perenes da escola histórica, cujos méritos não devem ser olvidados, nem descartada a sua metodologia de pesquisa histórica que sempre evitará uma banalização das ciências penais. No entanto século 19 teve representantes da escola históica do direito na Alemanha, que exageraram a sua influência e importância. Particularmente o grande penalista alemão Richard Loening exigia que o trabalho científico juridico no direit penal se limitasse a trabalhar a matéria do direito penal positivo exclusivamente do ponto de vista evolutivo histórico. Loening recusava qualquer análise filosófica e "de lege ferenda", direito $\mathrm{penal,} \mathrm{recusa}$ direito penal, recusa que defendia como principio básico. Um posicionamento tão extremado levou a uma visão estreita e ao entendimento errôneo que o direito positivo somente podia ser interpretado historicamente. A partir deste posicionamento foi necessário apenas um passo à interpretação terminológica histórica filológica alienada dos fatos da vida desembocando na jurisprudência de conceitos (Begriffsjurisprudenz). Os defensores desta escola passaram a examinar o direito em geral e o direito penal em particular, unilateralmente a partir de dentro, como sendo um todo pronto e completo, conceitualmente auto-suficiente. Das normas e dos conceitos próprios a cada ramo do direito os conceitos abstratos superiores do sistema eram obtidos pelo método indutivo. Os conceitos superiores sistematizados eram a seguir empregados, de forma estritamente lógica, para gerar principios decisórios para aqueles casos que não tivessem recebido uma regulamentação positiva expressa. Tal procedimento resultava num positivismo que tinha esquecido e descartado completamente o FIM das normas individuais afastando qualquer vinculação destas normas com a vida prática, passando a operar com uma metodologia exclusivamente morfológica interna ou interiorizada. Tal procedimento contras tava e entrava em conflito com a necessidade da existência de uma forma de observação do direito aberta e teleologica, que registrasse os in teresses da vida e os fins da legislação, para assim poder fixar o verdadeiro sentido e impacto das normas juridicas.

Nos pareceu importante detalhar esta situação assim descrita, pois Richard Loening, expoente da escola histörica positivista do direito penal na Alemanha, por uma daquelas estranhas coincidências históricas, no mesmo ano em que Franz von Liszt expôs o seu revolucionário "Programa de Marburg" para o direito penal portanto em 1882 , ao proferir o seu discurso como professor titular recém-admitido, de direito penal na Faculdade de Direito de Jena assim se manifestou:

"O direito penal apresenta-se para o futuro cientista penal e militante, como um direito em evolução, em formação e que nesta evolução revela a sua orientação o seu espírito, e que assim possibilita aos que o estudam descobrir o seu significado e o seu espirito e não para trazer para dentro do direito penal um outro significado. 0 direito penal dos nossos dias é quanto ao seu espirito e em relação aos seus detalhes e particularismos um produto da história".

$\mathrm{O}$ professor de direito, baseado nos resultados da pesquisa histórica, deve desenvolver os seus ensinamentos a respeito do direito positivo, e assim mostrar e desenvolver a importância do direito positivo em vigor. Este posicionamento, como se verá, entra em total choque e confronto com os ensinamentos e teorias de Franz von Liszt.

\section{AS CIÊNCIAS NATURAIS}

Em meados do século passado, a idéia da evolução passou a conquistar enorme importân cia como principio informativo da pesquisa. Os desdobramentos da teoria da evolução tiveram uma expansão enorme com a explosão das ciencias da natureza, a partir da segunda metade do século 19. Quando foi publicada em 1859 a obra de Charles Darwin "A Gênese das Espécies", irrompeu com toda força a teoria da evolução. Embora Darwin sempre defendesse sua teoria como sendo uma teoria das ciências naturais, foi impossivel evitar que as ciências do ine do direito bem como sociológicas também a acolhessem. Na Alemanha e na Áustria o Professor Adolf Merkel foi o arauto da teoria evolucionista no direito. (Adolf Merkel 1836-1896. Professor de Franz von Liszt em Viena). As aulas de Merkel em Viena e a teoria evolucionista tiveram profunda influência sobre 0 jovem Liszt e passaram a integrar a base do seu pensamento jurídico e ser o ponto nodal da sua revolucionária teoria do direito penal, teoria esta que ultrapassou todo pensamento juridico que embasava o direito penal do século 19 e que colocaria os fundamentos e iniciaria a evolução do Novo Direito Penal Social do século 20.

\section{FRANZ VON LISZT E A ESCOLA SOCIOLÓGICA} DO DIREITO PENAL

Franz von Liszt nasceu em Viena em 02/03/ 1851. É filho de uma familia de aristocratas austriacos, quase todos altos funcionários do governo: Seu pai, Eduard von Liszt, era Procurador Geral junto ao Supremo Tribunal austriaco em Viena. 0 mundialmente famoso músico de mesmo nome era seu primo irmão. Como veremos Franz von Liszt era genial como jurista, orador arrebatante, com um dominio fenomenal da língua alemã escrita. Era uma pessoa de dotes incomuns intuitivo, genial observador e dotado de grande charme pessoal aliado a uma impecável gentileza, incrivel capacidade de resposta certeira, mas sempre cheio de bondade e compreensão humana. Tais encomios eram também ratificados por seus muitos adversários. Estudou ciências juridicas e sociais na Universidade de Viena de 1869 a 1873 . Seus principais professores foram também todos fora de périe: Joseph Unger Rudolf von Jhering Julius série: Joseph Unger, Rudolf von Jhering, Julius Glaser, Wilhelm Emil Wahlberg e o grande Adolf Merkel. De todos Rudolf von Jhering exerceu a
influência mais duradoura. A idéia do fim, da finalidade para a norma e para o direito em geral e o direito penal em particular, tornou-se a motivação principal da obra jurídico-penal cientifica de Liszt. Mas não foram apenas os grandes professores de direito que influenciaram von Liszt. A Áustria daquele tempo padecia de graves problemas. Devem ser lembradas as derrotas militares frente aos exércitos prussianos, os problemas trazidos pela ocupação austríaca da Bósnia e da Herzegovina; contrastes e embates políticos e de nacionalidades e o grande problema da união com a Alemanha sob a égide prussiana. Verdadeiro dilema Hamletiano. Desde o berço afinado com a politica, Liszt além de jurista também foi grande politico austríaco, passando a liderar o partido Nacional-alemão da juventude acadêmica austriaca. Passou a odiar Napoleão o Terceiro e a admirar o Chanceler de Ferro Bismarck. Nunca perdeu seu interesse pela politica, a qual passou a determinar a sua postura juridico científica. $O$ direito penal passou a ser para ele politica criminal, o que viabilizou mais tarde a implementação das suas reformas penais propostas como jurista. Liszt foi pós-graduado em Goettingen e Heidelberg. Obteve a sua (1879) e a habilit căo para a catedra em Graz (1879) e a seguir inaugurou sua carreira como professo titular em Giessen. Após três anos foi para Marburg. Em 1889 lecionou em Halle e de 1899 até a sua aposentadoria em 1916 lecionou em Berlim. Morreu em Berlim em 21/06/1919. Suas primeiras obras juridicas são as seguintes: $\mathrm{Fal}$ so Juramento e Falso Depoimento - Um Estudo do Ponto de Vista do Direito Penal Histórico (1876); O Falso Depoimento em Juizo Segundo o Direito Alemão e Austríaco, (1877) Manual do Direito de Imprensa Austriaco (1878). Toda obras dotadas de extrema capacidade de sintese e clareza. Em 1881 publica o seu Manual do Direito Penal Alemão que teve 22 edicões. Esta obra consagrou Liszt como grande dogmático e sistematizador do direito penal alemão. A obra foi traduzida para diversas linguas e passou ser o livro texto ou manual lider da Europa.

Em 1882, como professor em Marburg, publica o seu famoso texto intitulado: Programa de Marburg - A Idéia do Fim no Direito Penal. Foi com esta obra que Liszt deslanchou a reforma do direito penal e uma profunda mudança na política criminal, ultrapassando de maneira revolucionária os conceitos do direito penal positivo então em vigor 
ção:

Já em 1893 von Liszt fez a seguinte indaga"O individualismo liberal que afirma os interesses do individuo com ênfase em relação à coletividade, o espirito da época do iluminismo e a revolução francesa dela resultante, trouxeram-nos a forte limitaça do poder estatal poder estatal de punir. alizante que está começando a se manifestar levará ou não de roldão o estado atual do direito penal? No que me diz respeito devo dizer com franqueza que não me importaria muito se 0 atual código de direito penal, seus intérpretes, elucidadores e aplicadores fossem levados pela onda. Estou antevendo que o estado socialista, que está se formando, certamente vai afirmar com mais força os interesses da coletividade do que o fazemos hoje em dia. Este estado socialista assim procederá, pois agirá com mais intensidade, com maior certeza dos seus fins e com muito menos consideração contra o individuo que contra ele se rebela. Por isto será necessário fixar para este estado as pré-condições, segundo as quais o individuo, quanto aos seus interesses, deve submeter-se à coletividade. Será também necessário determinar os limites até os quais será permissivel e admissivel que ocorra perda de proteção legal para 0 individuo. Segundo a minha opiniāo, embora isto soa paradoxal, vejo o código penal como sendo a Magna Carta do criminoso. Em verdade 0 código penal e as suas normas não protegem nem a coletividade nem a ordem juridica, mas 0 individuo que se rebela contra ambos. O código penal the assegura o direito de somente ser punido segundo as précondiçōes legais e somente dentro e de acordo com a limitação legal. A frase dupla latina Nullum Crimen Sine Lege, Nulla Poena Sine Lege, é a defesa máxima do cidadão contra o super-poder do estado, defesa também contra o poder, sem quaisquer considerações, da massa, enfim a defesa contra o Leviathan. Há anos defino o direito penal como poder de punir do estado limitado pela lei. Agora posso também afirmar que o direito penal é a barreira impassável da politica criminal."

\section{O FULCRO DA PREGAÇÃO DE FRANZ VON} LISZT

Quando Liszt assumiu a sua última cátedra em Berlim em 1899 disse que o direito penal, as ciências penais, tinham três tarefas que deviam por elas ser atendidas:

1. A tarefa pedagógica da formação do jurista penal: Esta formação deveria ser dúplice. De um lado a formação tradicional jurídico penal, do outro lado, acoplada a uma formação criminalistica. Criminalistica aqui significando o conjunto de métodos e experiências necessário para a constatação dos fatos, o descobrimento e a entrega à polícia dos delinqüentes, a reconstrução das imagens do ato delituoso de parte da policia criminal, da promotoria e em juizo, uma ciência ou um ramo do conhecimento que naquele tempo ainda não tinha conquistado um espaço autônomo na formação científica dos juristas penais.

2. A tarefa do reconhecimento cientifico do delito e da pena: $\mathrm{O}$ uso da metodologia das ciências naturais, que utilizando o esclarecimento causal do delito, o pesquisa como fato individual e também social. Que pesquisa as origens do delito e o tipo humano e características do delinqüente. Que pesquisa também as possibilidades de atuação e efeitos da pena. Portanto para Liszt a criminologia e a penologia são ramos das ciências penais. A tudo isto deve se somar a pesquisa histórica da evolução do delito, da própria delinqüência e dos modos como a sociedade ao longo dos tempos reagiu em relação a tais ou quais atos delituosos.

3. Todo este conjunto de material empírico formará a base para a solução da terceira tarefa da política criminal: Utilizando a idéia da teoria da evolução deve ser pesquisada a tendência futura para qual se movimenta a história do delito e das penas, para detectar desde já para o legislador como deverá ser a evolução futura do direito penal. A política criminal fornecerá as bases cientificas para responder à pergunta ou indagação se o direito penal em vigor é passivel de melhoria e segundo quais métodos o combate à criminalidade deverá ser montado implementado. $\mathrm{O}$ trabalho De Lege Ferenda, afastado por Richard Loening, passa ser uma tarefa importante e autônoma das ciências penais. Pesquisa-se, enfim, se o direito penal positivo é capaz de diminuir a criminalidade existente e se atende e preenche o seu esperado fim social.

Por conseguinte 0 trabalho do criminalista não se esgota no jurídico. Devem ser cultivadas as relações para com outras ciências naturais tais como: antropologia, psicologia, psiquiatria biologia e também sociologia.

Assim Franz von Liszt procurou resolver complexo problema da punição pelo estado, sugerindo e empregando, de forma genial novo métodos. Nisto foi apoiado pela Associação Criminalística Internacional por ele fundada e que em famosos seminários reuniu homens famosos cientistas penais de escol, tais como: Robert von Hippel, Ernst Rosenfeld, Eduard Kohlrausch, Moritz Liepmann, Alexander Graf Zu Dohna, Ernst Hafter, Franz Exner, Ernst Delaquis, Gustav Radbruch, Herbert Engelhardt Eberhard Schmidt, todos catedráticos de direito penal ilustres.

\section{FRANZ VON LISZT E A ESCOLA DA}

ANTROPOLOGIA CRIMINAL DE CESARE

\section{LOMBROSO}

Franz von Liszt sempre se manteve reservado e crítico em relação às pesquisas de Cesare Lombroso (médico 1836-1909). Como jurista Liszt tinha graves dúvidas metodológicas em relação às teorias de Lombroso. Pois delito é um conceito juridico legal. A lei diz o que deve ser considerado um delito. $\mathrm{E}$ a lei muda ao longo da história. $\mathrm{O}$ que era delito ontem, hoje não mais é. Por exemplo: os processos de bruxaria e mágicos da Idade Média, hoje não têm mais sentido penal. O conflito com Lombroso foi inevitá vel. Liszt entendia que em relaçäo ao delito, ao fenômeno ato delituoso deveria ser apalpad toda a realidade do delito, na medida que isto era factivel, utilizando observações empiricas cientificas. Liszt entendia que era absolutamente necessário conhecer o delito biológica e socialmente, para, uma vez por todas fugir das conceituações nebulosas de uma construção racional da pessoa do delinqüente. Liszt queria conhecer o delinqüente como ele verdadeiramente é. O inimigo tinha que ser reconhecido para po- der testar criticamente as medidas de defesa e então instalá-las adequadamente. Lombroso, nas suas pesquisas arrojadas a respeito de 'uomo Delinquente acreditava ter descoberto 0 Delinqüente Nato: aquela espécie do Homo Sapiens que na sua estrutura anatômica e suas sensibilidades apresenta características antropológicas, cientificamente constatáveis, que permitiriam concluir que se tratava de um delinqüente em potencial. Não se discute que Lombroso tem o mérito imorredouro de ter estabelecido como primeiro e com muita ênfase o método da pesquisa causal em relação a uma variedade enorme de delinqüentes, focalizando assim um facho de luz elucidativa sobre muitos tipos de delinqüentes. Mas quem determina 0 que deve ser considerado delito è o legislador, num exercício de estudo e observação valorativo de possiveis comportamentos. Como então seria possivel que tais conceitos valorativos do legislador passem a ser os limites e natureza de fenômenos que se manifestam nas ciências naturais, como por exemplo esta espécie especial do Homo Sapiens caracterizada por Lombroso. Ou por outra, como seria possivel que o conceito jurídico e legal de delito, que é submetido às mudanças, no tempo, das valorizações sociais, passe a ser determinante para a formação conceitual das ciências naturais? Todos sabemos que os objetos empiricos das ciências naturais em seu "Ser Assim" são totalmente independentes de valorizaçōes ou considerações valorativas humanas. Liszt então considerou erradas as posiçōes que consideram o delinqüente de acordo com uma conceituação puramente biológica, uma conceituação do criminoso a partir da $E x$ clusiva dedução oriundas das caracteristicas fisicas e mentais do delinqüente. Não existe, afirma Liszt, um tipo de delinqüente singular antropológico. Opõe à teoria antropológica de Lombroso a sua teoria sociológica, mas não a opõe excluindo a antropologia, propondo ao contrário que estudos sociológicos, unidos aos estudos antropológicos podem auxiliar na elucidação das razōes do delito.

As teorias de Lombroso passaram a ser defendidos pelos juristas italianos E. Ferri e R. Garofalo que fundaram a escola de antropologia criminal, tendo FERRI publicado sua obra principal em 1881 intitulada nuovi orizzonti del diritto e della procedura penale. 
FRANZ VON LISZT E A ESCOLA CLÁSSICA O Litígio das Escolas

A escola moderna de Franz von Liszt logo entrou em choque com a escola clássica, cujo principal representante na Alemanha era Kar Binding (1841-1920) que era sucessor do pensamento de Kant e Hegel, e defendia a teoria absoluta do direito penal (A pena representa uma perda de direitos ou bens jurídicos que o Estado impõe legalmente ao delinqüente para logra a satisfação do ato culposo, irreparável, de que bra do direito e para manter integra a autoridade do direito (da norma lesionado). (Binding). "As bases do direito penal alemão." Parte Geral, sétima edição, 1907, p. 226).

$O$ litigio entre a escola moderna de Liszt e a teoria absoluta, findou na Alemanha na década dos anos vinte, sendo que a teoria de Liszt que passou então a ser conhecida como sendo a teoria da ressocialização, das medidas de segurança impostas como pena ao delinqüente, passou a ser inserida no Código Penal Alemão e legislação complementar sob a chamada teoria da Unificação - Vereinigungs - Theorie. A pena passa a ser considerada como a justa retaliação mas, dentro do escopo da pena assim aplicada (teoria absoluta) devem ser consideradas e ponderadas medidas de prevenção geral e especial.

A preferência por uma ou outra das teorias de direito penal varia de sociedade para sociedade, de governo a governo. Na Alemanha de 1871 (ano da unificação) até a $1^{\text {a }}$ Guerra Mundial predominava a teoria absoluta, mas que tinha que defender-se de fortes criticas e ataques de outras escolas.

Durante a época da primeira guerra mundial passou a aplicar-se a teoria da retribuição (absoluta) misturada com medidas de prevenção geral. Durante a República de Weimar aplica-se a teoria da unificação que se afirma tanto nos trabalhos práticos como teóricos grangean do simpatia todavia à teoria moderna de Lisz da ressocialização. O Terceiro Reich de Hitler inicia com a teoria absoluta (retaliação/expiação) e descamba durante a $2^{\mathrm{a}}$ Guerra Mundial para uma brutal teoria da atemorização (extensão da pena de retribuição/retaliação à familia do delinqüente). Após a Segunda Guerra Mundial passa-se na Alemanha a aplicar a teoria da unificação completa, com ênfase na teoria ab- soluta. A partir da segunda metade dos anos sessenta volta-se a preferir a teoria da ressocialização que se manifesta especialmente no artilizaça que se manifesta especialmente no artgo $2^{\circ}$, alinea $1^{\text {a }}$ da lei de execuções penais alemã de 1977 (Durante o cumprimento da pena de privação da liberdade o preso deve adquirir a capacidade de futuramente viver uma vida com responsabilidade social e sem cometimento de delitos). Presentemente no entanto, há indicios muito claros de um retorno à teoria absoluta da retribuição. Grande interesse também tem, novamente, a teoria da prevenção geral. A discussão atual na RFA gira ao redor das medidas de intensificação do combate à delinqüência; a preocupação em aumentar a quota de sucesso nos esforços de esclarecimentos de crimes cometidos; a expansão da aplicação da pena de prisão durante a fase investigatória; a preocupação sempre crescente com modernas técnicas e ato delituosos tais como: crimes contra a economia crimes contra o meio ambiente; criminalidade organizada (drogas especialmente, furto de automóveis); crimes contra a proteção de dados: crimes contra o uso correto do computador.

\section{O Legado de Franz von Liszt}

Franz von Liszt, como professor de direito penal, foi o primeiro que transpôs os métodos o conceito de ciência do positivismo para o direito penal. Ao definir o âmbito de "toda ciência do direito penal", nele incluiu, como já visto, a criminologia e a penologia (um termo por ele cunhado). A criminologia para ele tem a função de explicar as causas do delito, enquanto a penologia deve estudar as causas e os efeitos da pena. O direito penal, como teoria absoluta, da retribuição ou vingança, para Liszt, era apenas de importância secundária. Ao proferir sua aula inaugural na Faculdade de Direito da Universidade de Marburg em 1882, sem dúvida conhecedor dos trabalhos e das pesquisas, de Cesare Lombroso, Enrico Ferri e Rafaele Garofalo, Liszt. lançando sua doutrina da nova prevenção especial, obteve com esta doutrina, como construção racional abstrata, grande repercussão internacional, ao mesmo tempo remodelando profundamente o sistema de sanções do direito penal alemão. Para Liszt a concreticidade e a realidade da criminalidade é fundamental. Tanto a pré-disposição individual antropológica, em es- cala menor, quanto o meio ambiente, em escala bem maior, são fatores indispensáveis para 0 surgimento da criminalidade. Todavia sempre preponderando os fatores sociológicos. Segundo Liszt o direito penal deve sempre orientar-se segundo o fim, o objetivo a que se destina. 0 direito penal deve apresentar uma utilidade, um feito util, que seja capaz de ser registrado e ser efeito util que seja capaz de ser registrado e ser captado na estatistica criminal. Partindo destes pressupostos, demonstrou os defeitos do sistema penal alemão vigente à época e partiu para a formulação de um programa de reforma no sistema. Este programa passou a considerar a politica criminal como parte orgânica da politica social e que era dirigido por metodos de pesquisa de natureza causal e empirica segundo o exemplo das ciências naturais. Segundo Liszt, o combate à criminalidade deve iniciar nas raizes do delito. O programa de reforma deve acima de tudo modificar os estados sociais. Para Liszt a pena correta, isto é, a pena justa, é a pena necessária. Justiça no e para o direito penal é a correta observação da medida necessária da pena em decorrência das exigências do fim que informa a norma juridica. Para Liszt o direito penal tem a tarefa de dar ao delinqüente eventual, ocasional, que não necessita ser ressocializado, um lembrete suficientemente forte para atemorizá-lo e assim não mais delinqüir. Já o delinqüente semi habituc cado e de se reabilitar deve ser ressocializado por métodos educacionais durante o processo de execução da pena. Finalmente, o criminoso habitual deve ser neutralizado por imposição de medidas de "servidão penal" (Strafknechtschafit) por tempo indeterminado. Um dos aspectos mais importantes da penologia de Liszt era a mutacão da pena como sendo uma reação cega dos sentidos, que exige e impóe vingança e retribuisentidos, que exige e impoe vingança e retribui-
ção, para uma ação racional cônscia do seu fim ção, para uma ação racional conscia do seu fim ca, que Liszt mais tarde completaria com a sua teoria famosa a respeito dos tipos de delinqüentes, Liszt procurou eliminar, ou ao menos combater, a nocividade da imposição da curta pena de privação de liberdade causadora, segundo ele de tantos maléficos "pois leva, invariavelmente o jovem aprendiz para o caminho do crime".
No ano de 1889 Liszt e o belga Adolphe Prins, bem como o holandês G.A. Van Hamel, fundaram a Associação Internacional de Criminalistica Esta associação defendeu até o advento da primeira guerra mundial uma nova politica criminal. No ano de 1924 estes trabalhos foram retomados pela Associação Internacional de Direito Penal. Hoje programa de politica criminal é continuado pela Sociedade Internacional de Defesa Social fundada em 1947 pelo italiano Filippo Grammatica. O principal representante desta sociedade hoje em dia é Marc Ancel. A expressão "Défense Social" significa hoje o conceito abrangente de todas as medidas da sociedade contra delinqüentes apenados, que tem a finalidade de ressocializar apenados, que ter
estas pessoas

Liszt deu portanto à idéia, já antiga, da "pena com um fim" originária do positivismo, um empuxe novo e muito forte. Ao redor dele formouse a escola alemã de direito penal, moderna, sociológica, cujos representantes Kohlrausch, se opunham Radbruch e Eberhardt rontalmente aos adeptos da antiga escola clás sica à qual pertenciam Binding, Beling e Birkmayer

Pertence também à Liszt o sistema, simples e claro que analisa e subdivide 0 ato delituoso em Tatbestand, Rechtswidrigkeit e Schuld. Ato/ fato delituoso, infringência da norma juridica $e$ culpa. Sistema que durante geracões auxiliou no estudo do direito penal. Em 1923 a lei alemã reguladora e disciplinadora dos crimes da juventude passou a adotar as idéias de Liszt. Em 1933 foram introduzidas as medidas de segurança e de melhoria no direito penal alemão.

Em 1968 os pequenos delitos ("Bagatelldelikte") foram convertidos em contravencōes penais não-criminais. E, finalmente, em 1969 ocorreu na Alemanha uma reforma fundamental do sistema de sanções. A pena de reclusão discriminadora foi abolida, o cumprimento unificado da pena em liberdade foi introduzido. A pena pri vativa de liberdade de curta duração foi limita da. 0 catálogo das medidas de segurança e de melhoria do delinqüente foi aumentado. Ainda está presente e bem vivo o que o mestre Franz von Liszt ensinou há mais de cem anos. 


\section{NOTAS DE REFERÊNCIA}

1 George Wilhelm Friedrich Hegel (1770-1831) discipulo de Kant, ensinou e afirmou que o delito é a negação da norma. Portanto o delito é algo negativo. Este negativo é negado por um segundo negativo, que recompōe a ordem de normas lesionadas pelo delito. Portanto segundo Hegel, a pena é a negaçào da negaç, ria para a manulençáo e exlstencia da ordem juridica.

2 Cesare Beccaria (1738-1794) de Milano, com seu livro Dei Delitti e Delle Pene publicado em 1764, opôs-se às déias de Kant; afirmou que a razão do punir não é a retribuição ou a vingança mas sim 0 bem comum. A razão é evitar que delitos sejam cometidos.

\section{BIBLIOGRAFIA}

FUCHS, Dieter. Ewald Schellenberger - "Recht",

AAFT, Fritjof. "Aus der Waagschale der Justitia" - "Da Balança da Justiça" Beck dtv, 1990.

MAYER, Helmuth. "Strafrecht Allgemeiner Teil" (Direito Penal) Parte Geral. Ed. W. Kohlhammer 1953.

DBRUCH, Gustav. "Elegantiae juris criminalis". "Sieben Studien zur Geschichte" des Strafrechts, 2.ed. 1950

MIDT, Eberhard. Einfuehrung in die Geschichte der deutschen. Strafrechtspflege. Introdução à História do Direto Penal Alemáo. Ed. Goettingen 1951.

Direito Penal. Wolfgang Naucke. Eine Einfuehrung 1991.

WESEL, Uwe. Juristische Weltkunde. História Jurídica Mundial. Ed. Suhrkamp 1984 Taschenbuch. Wissenschaft. 